\title{
Dissolved organic matter release in a Posidonia oceanica meadow
}

\author{
Cristina Barrón ${ }^{1,2, *}$, Carlos M. Duarte ${ }^{1}$ \\ ${ }^{1}$ IMEDEA (CSIC-UIB), C/ Miquel Marqués 21, 07190 Esporles (Islas Baleares), Spain
}

${ }^{2}$ Present address: Vrije Universiteit Brussel, Analytical and Environmental Chemistry, Pleinlaan 2, 1050 Brussels, Belgium

\begin{abstract}
We examined annual nutrient changes (nitrate, phosphate and ammonium) and the net dissolved organic carbon (DOC), nitrogen (DON) and phosphorus (DOP) release using in situ benthic incubations in a Posidonia oceanica meadow and in unvegetated sediments of Magalluf Bay (Mallorca Island, Spain) at monthly intervals. We also examined the role of the $P$. oceanica meadow in the $\mathrm{C}: \mathrm{N}: \mathrm{P}$ ratio transformations by comparing the ratios between the inorganic and dissolved organic fluxes in the seagrass ecosystem and those in the plant material. Our results indicate that $P$. oceanica communities enhance DOC fluxes relative to adjacent unvegetated sediments. The net DOC release from the $P$. oceanica meadow represents $71 \%$ of the net community production. The C:N:P ratio in the flux of dissolved organic material (DOM) from the P. oceanica community (1450:69:1) exceeded the C:N:P ratio in the DOM flux of unvegetated sediment communities. The high flux of DOC release from this seagrass community might be enriched in carbon compounds, as these plants produce nonstructural carbohydrates in excess.
\end{abstract}

KEY WORDS: Benthic fluxes · Seagrasses $\cdot$ Dissolved organic carbon $\cdot$ Posidonia oceanica $\cdot$ Dissolved organic matter $\cdot$ Carbohydrates

\section{INTRODUCTION}

Seagrass meadows rank among the most productive ecosystems and are generally net autotrophic, with an excess of organic carbon production relative to community respiration (Duarte \& Cebrián 1996, Gattuso et al. 1998, Duarte \& Chiscano 1999, Hemminga \& Duarte 2000). The excess production in seagrass ecosystems is either stored in the sediments or exported to adjacent waters (Duarte \& Cebrián 1996, Duarte et al. 2005). Export of organic matter from seagrass ecosystems is believed to occur mainly as litter, which channels about $25 \%$ of the net primary production of the plants (Duarte \& Cebrián 1996). However, seagrasses are also known to release important amounts of dissolved organic carbon (DOC; Brylinsky 1977, Penhale \& Smith 1977, Wetzel \& Penhale 1979, Moriarty et al. 1986). Some of the DOC released may be used locally and exported from the meadow. The DOC released by the seagrass ecosystem may be contributed by differ- ent components of the ecosystem such as exudation by epiphytes, excretion and sloppy feeding by consumers, and diffusive release from sediments. Yet, most studies on DOC release by seagrass focus on the DOC released directly by the leaves and ignore the contribution of other ecosystem components to DOC release and DOC use. Hence, the net DOC release (gross release - consumption) by seagrass ecosystems, which is the pool available to export, has seldom been assessed (Velimirov 1986, Ziegler \& Benner 1999a, Barrón et al. 2004, Ziegler et al. 2004).

Dissolved organic matter (DOM) loss from seagrass meadows also represents a loss of nutrients, as DOM contains nitrogen $(\mathrm{N})$ and phosphorus $(\mathrm{P})$. Hence, the export of DOM from seagrass meadows also involves a loss of $\mathrm{N}$ and $\mathrm{P}$, the significance of which depends on the magnitude of these fluxes. In order to sustain their high production (Hemminga \& Duarte 2000), seagrass meadows must balance their nutrient inputs and losses. Whereas seagrass nutrient budgets have been 
assessed in the past (e.g. Hemminga et al. 1991, Pedersen \& Borum 1993, Gacia et al. 1999), most of these have focused on inputs, rather than losses, and have not directly addressed fluxes associated with DOM fluxes, with some exceptions (Dollar et al. 1991, Ziegler et al. 2004). Furthermore, still very little is known about the fate of DOM fluxes in these ecosystems. However, the fact that seagrass ecosystems tend to be net autotrophic implies that they must take up inorganic nutrients and release nutrients in organic form. The examination of the balance between dissolved inorganic nutrient incorporation and dissolved organic nutrient loss will improve present understanding of nutrient budgets of seagrass meadows, particularly in the oligotrophic environments they often inhabit. The examination of the $\mathrm{C}: \mathrm{N}: \mathrm{P}$ atomic ratio of the DOM fluxes from seagrass ecosystems, which typically have tissue $\mathrm{C}: \mathrm{N}: \mathrm{P}$ ratios higher than the Redfield ratio (Atkinson \& Smith 1983, Duarte 1990) may also provide insight into the possible relevance of these fluxes in the ecosystem.

Posidonia oceanica (L.) Delile is an endemic Mediterranean seagrass species that forms extensive meadows with high above- and below-ground biomass and primary production (Duarte \& Chiscano 1999, Hemminga \& Duarte 2000). P. oceanica is slow-growing, with a rhizome elongation of only a few ${\mathrm{cm} \mathrm{yr}^{-1}}^{-1}$ and a shoot elongation of $<1 \mathrm{~cm} \mathrm{yr}^{-1}$ (Duarte 1991). It often grows in oligotrophic environments, such as those present in the Balearic Islands (Spain; Gazeau et al. 2005). The excess production of $P$. oceanica is stored in the sediments, similar to that of other seagrass species (e.g. Mateo et al. 1997, Gacia et al. 2002), or exported either as particulate detritus, which can form extensive banks along the coastline (Mateo et al. 2003), or as DOC (Velimirov 1986).

In the present study, we report annual inorganic nutrient uptake (nitrate, phosphate and ammonium), net DOM release (DOC, DON and DOP) and the C:N:P ratio of these fluxes by a Posidonia oceanica meadow relative to the fluxes observed in adjacent unvegetated sediments. We examined this at monthly intervals using in situ benthic chambers to assess the role of the $P$. oceanica meadows in the release of DOM as well as the associated nutrient budget. Finally, we also estimate the carbon balance at the study site and the export of DOC from this coastal ecosystem to the adjacent open ocean.

\section{MATERIALS AND METHODS}

The present study was conducted in a Posidonia oceanica meadow at $7 \mathrm{~m}$ depth and in unvegetated sediment in Magalluf Bay (Mallorca Island, Spain, $39^{\circ} 30.23^{\prime} \mathrm{N}, 2^{\circ} 32.60^{\prime} \mathrm{E}$; cf. Gazeau et al. 2005). At this site, the sediment is mainly composed of biogenic coarse $(<0.5 \mathrm{~mm})$ to fine $(<0.125 \mathrm{~mm})$ sands, with $>90 \%$ content in $\mathrm{CaCO}_{3}$ (Diaz del Rio et al. 1994). Net community production (NCP) and DOC fluxes were studied at approximately monthly intervals from March 2001 to October 2002. Estimates of inorganic fluxes (nitrate + nitrite, phosphate and ammonium) and net DON and DOP fluxes were obtained concurrently from incubations in benthic chambers deployed at approximately monthly intervals from June 2001 to October 2002.

Benthic metabolism, DOM fluxes and inorganic fluxes were examined in situ using benthic chambers deployed at a depth of $7 \mathrm{~m}$ by divers. Four chambers were used to incubate the Posidonia oceanica community, and 3 additional chambers were set up in adjacent unvegetated sediments. The in situ benthic chambers consisted of a PVC cylinder $(18 \mathrm{~cm}$ in diameter) inserted about 7 to $10 \mathrm{~cm}$ deep into the sediment and a gas-tight polyethylene plastic bag (Hansen et al. 2000) fitted onto the cylinders by the divers. These benthic chambers allowed us to estimate the net fluxes of the $P$. oceanica community and its surrounding water as well as unvegetated sediments, evaluating the whole benthic community system (e.g. sediment, seagrasses meadows, epiphytes, plankton, bacterial community). The polyethylene plastic bag had a sampling port in order to collect water samples with $50 \mathrm{ml}$ (polyethylene), acid-washed syringes. The flexible nature of the polyethylene plastic bags allowed turbulence to propagate in the interior of the benthic chamber, providing mixing. The resulting mixing times (on the order of $5 \mathrm{~s}$ ) were assessed by injecting a fluorescent dye (fluorescein) into the chambers. Benthic chambers were deployed in the morning, and the enclosed water was, after mixing the water inside the chamber, sampled initially, just before sunset and right after sunrise. The volume of each chamber was estimated by injecting $5 \mathrm{ml}$ of a $0.25 \mathrm{~mol} \mathrm{l}^{-1}$ phosphate solution into each chamber at the end of the experiment, allowing $5 \mathrm{~min}$ for mixing, and determining the resulting dilution. Estimates of the possible bias due to uptake and adsorption during these $5 \mathrm{~min}$ showed this to be negligible $(<0.1 \%)$. The water samples were collected and kept frozen until spectrophotometric determination of the phosphate concentration after Hansen \& Koroleff (1999). The volume of water enclosed in the benthic chambers was, on average, $5 \mathrm{l}$. The $P$. oceanica leaves enclosed in each benthic chamber were harvested at the end of the experiment, rinsed and scraped with a razor blade to remove the adhering epiphytes, and then dried at $60^{\circ} \mathrm{C}$ and weighed to estimate the $P$. oceanica leaf biomass. The $\mathrm{C}$ and $\mathrm{N}$ content of the 
$P$. oceanica leaves were analyzed using a CHN analyzer, and the P content was analyzed spectrophometrically following persulfate digestion.

The monthly NCP was estimated from dissolved oxygen (DO) concentration changes. The DO was measured using the Winkler method (Carritt \& Carpenter 1966) with an automated titration system (Mettler DL21 Auto-titrator) with potential redox electrode end-point detection (Oudot et al. 1988). Hourly rates of community respiration (R) and NCP were estimated from the difference in DO concentration in the chambers at night and during the day, respectively. Hourly rates of gross primary production (GPP) were computed as the sum of the hourly rates of R and NCP. Daily rates of GPP were calculated by multiplying the hourly GPP by the photoperiod. Daily rates of $\mathrm{R}$ were calculated by multiplying the hourly $\mathrm{R}$ by $24 \mathrm{~h}$. Daily rates of NCP were estimated as the difference between daily rates of GPP and R. Metabolic rates in DO units were converted to carbon units assuming photosynthetic and respiratory quotients of 1 ; this value is used widely in seagrasses, although there are not many empirical conversion factors available for seagrass. This equivalence is assumed for terrestrial plants that use starch and sugars as respiratory substrates, which are also the respiratory substrates of Posidonia oceanica (Alcoverro et al. 2001). Hence, this conversion appears to be supported, although variability of these quotients may introduce errors into the estimates, as discussed in detail by Kirk (1983). DO concentrations in $P$. oceanica benthic chambers at the beginning of the experiment were, on average, $6.95 \mathrm{mg} \mathrm{O}_{2} \mathrm{l}^{-1}$, while at dusk, the DO concentrations were, on average, $12.17 \mathrm{mg} \mathrm{O}_{2} \mathrm{l}^{-1}$. This increase in the DO during daytime seems relatively moderate, minimizing artifacts due to physiological stress on $P$. oceanica leaves or due to unrealistically high oxygen values (oxygen supersaturation) at the start of the dark incubation period. Besides, the DO value at the end of the incubation periods were, on average, $6.75 \mathrm{mg} \mathrm{O} \mathrm{O}_{2} \mathrm{l}^{-1}$, meaning that the decrease of DO at night is relatively moderate, thus minimizing artifacts due to unrealistically low oxygen values at the end of the dark incubation period. We elected to calculate oxygen and DOC fluxes during $24 \mathrm{~h}$ intervals rather than using time series because the estimation of GPP and NCP from time-series measurements is not correct, as these processes are not linear (due to changing nightlight processes), whereas the use of $24 \mathrm{~h}$ intervals integrates all the GPP and NCP variations. In addition, we elected to calculate oxygen changes over $24 \mathrm{~h}$ intervals, which allowed calculation of NCP, to allocate our effort to setting up replicate benthic chambers with a fairly high temporal coverage (monthly intervals over $1.5 \mathrm{yr}$ ). Some of the uncertainties of using benthic chambers include the possible exchange of metabolic products horizontally across the sediment (Huertel \& Gust 1992). Possible resuspension of material due to handling of the benthic chambers was avoided by starting the initial sampling after setting up all the chambers.

Fluxes of dissolved inorganic (nitrate, phosphate and ammonium) and organic (DOC, DON, DOP) matter were based on the rate of concentration change between initial to final (right after sunrise) samples. Water samples from the benthic chambers were filtered through pre-combusted $\left(450^{\circ} \mathrm{C}\right.$ for $\left.4 \mathrm{~h}\right) \mathrm{GF} / \mathrm{F}$ filters. DOC samples collected from March 2001 to May 2001 were kept frozen in acid-washed material (glass vials encapsulated with silicone-Teflon caps) until analyses. DOC samples retrieved subsequently were kept acidified with $2 \mathrm{~N} \mathrm{HCl}$ at room temperature in acid-washed ampoules. DOC samples were analyzed on a Shimadzu TOC-5000A (Benner \& Strom 1993). DOC standards, provided by D. A. Hansell and W. Chen (University of Miami), of 44 to $45 \mu \mathrm{mol}$ DOC and $2 \mu \mathrm{mol}$ DOC were used to assess the accuracy of the estimates. The instrument blank ranged between 0 and $7.59 \mu \mathrm{mol}$ DOC $\mathrm{l}^{-1}$ across the different analytical batches. Samples for nutrient analysis were kept frozen in acid-washed containers until analysis. Total dissolved $\mathrm{N}$ and $\mathrm{P}$, phosphate and nitrate were measured using a UV oxidation standard method (Hansen \& Koroleff 1999) in a Bran+Luebbe AA3 Autoanalyzer. Ammonium concentration was assessed spectrofluorometrically (Kérouel \& Aminot 1997). DON was calculated as the difference between total and inorganic dissolved nitrogen (ammonium + nitrate), and DOP was calculated as the difference between total dissolved $\mathrm{P}$ and phosphate. The detection limits of the total dissolved $\mathrm{N}$ and $\mathrm{P}$ were 0.3 and $0.06 \mu \mathrm{M}$, respectively. The limits of DON and DOP flux measurements were $0.058 \mathrm{mmol} \mathrm{N} \mathrm{m}^{-2} \mathrm{~d}^{-1}$ and $0.012 \mathrm{mmol}$ $\mathrm{P} \mathrm{m}^{-2} \mathrm{~d}^{-1}$, respectively. These estimates were based on the detection limits and the coefficients of variation of 0.38 and $0.3 \%$ for nitrogen and phosphate, respectively. Stoichiometry ratios were calculated for all pools and dissolved organic fluxes whenever both fluxes (from each benthic chamber) taken into account in the stoichiometry ratio (DOC:DON, DOC:DOP and DON:DOP) were significant, consistent (uptake or release) fluxes. Annual rates of NCP, fluxes of nitrate, phosphate and ammonium, net DOC, DON and DOP fluxes and stoichiometry ratios were calculated as averages of the last 12 mo estimates, so that they could be directly compared.

Student's $t$-test $(\alpha=0.05)$ was used to determine whether nutrient (nitrate, phosphate and ammonium) fluxes and the net DOC, DON and DOP fluxes in a 
Posidonia oceanica meadow and unvegetated sediments were significantly different from zero. We used a $t$-test to test for the statistical significance of individual rates and annual mean rates, which were log-transformed when necessary to comply with the requirements of the analysis. We used the Wilcoxon signed-rank test to test for a significant tendency for the time series (all the months studied) to consistently support positive or negative (release vs. uptake) rates.

\section{RESULTS}

The leaf biomass of Posidonia oceanica in the benthic chamber was high in spring (April 2001) and in summer (August 2002), with $859.0 \pm 146.6$ and $880.5 \pm$ $145.6 \mathrm{~g} \mathrm{DW} \mathrm{m}^{-2}$ (mean $\pm \mathrm{SE}$ ), respectively, and reached minimum values during fall.

NCP showed a similar pattern to that of leaf biomass, except for an earlier spring maximum (Fig. 1). Because of high variability among plots, $75 \%$ of the NCP values in the Posidonia oceanica meadow differed significantly from zero ( $t$-test; $\mathrm{p}<0.01)$. The nutrient concentration in $P$. oceanica leaves (without epiphytes) during the study period (as \% DW, mean \pm SE) was $38.5 \pm$ $0.4 \mathrm{C}, 1.9 \pm 0.1 \mathrm{~N}$ and $0.2 \pm 0.01 \mathrm{P}$, equivalent to an atomic C:N:P ratio of 497:21:1 and a C:N ratio of 24 .

$\mathrm{NCP}$, net inorganic fluxes (nitrate + nitrite, phosphate and ammonium) and net DOC, DON and DOP fluxes reflected the fluxes in the whole Posidonia oceanica community (seagrass, sediment below and water canopy) and in the unvegetated community

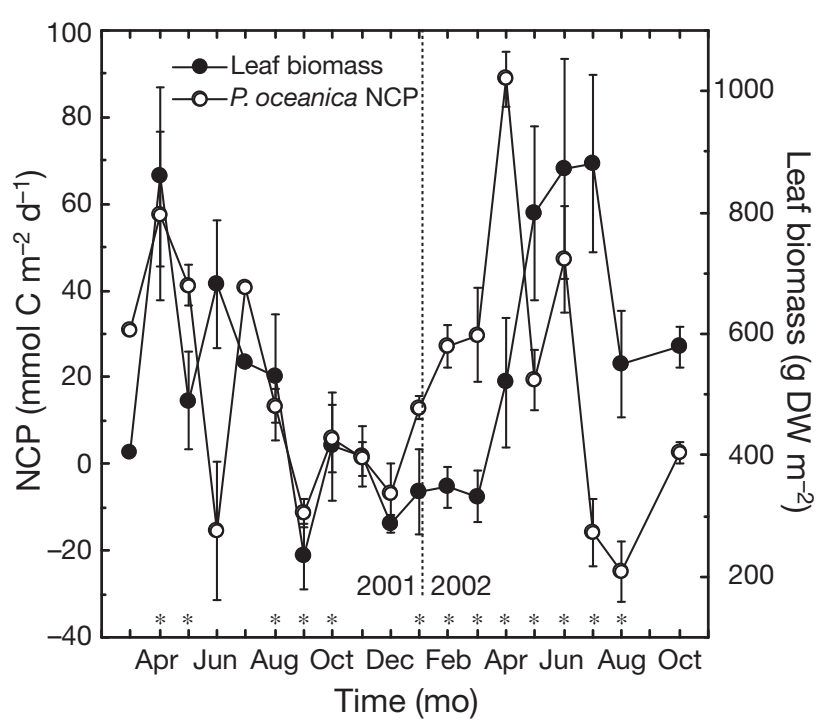

Fig. 1. Posidonia oceanica. Leaf biomass and net community production $(\mathrm{NCP})$ over the study period (mean $\pm \mathrm{SE}$ ). Asterisks indicate NCP values are significantly different from zero $(t$-test) (unvegetated sediment and surrounding water). Annually, the $P$. oceanica meadow acted as a net sink of nitrate (Table 1), with an average net nitrate uptake of $10.2 \pm 4.6 \mathrm{mmol} \mathrm{N} \mathrm{m}{ }^{-2} \mathrm{yr}^{-1}$ statistically significant from zero ( $t$-test; $\mathrm{p}<0.05$ ). At $62 \%$ of the sampling events, net nitrate uptake was not significantly different from zero (Wilcoxon test; $\mathrm{p}>0.05$ ) and high uptake rates were found in spring, concurrent with the highest NCP rates (Figs. $1 \& 2 \mathrm{a}$ ). Unvegetated sediments supported an annual net release of $4.0 \pm 3.2 \mathrm{mmol} \mathrm{N} \mathrm{m}^{-2} \mathrm{yr}^{-1}$, which was statistically significant $(t$-test; $\mathrm{p}<0.05)$, with a pulse in late summer of 2002 (Table 1, Fig. 2a). However, half of the sediment nitrate fluxes in the unvegetated sediments were not significantly higher than zero (Wilcoxon test; $\mathrm{p}>0.05$ ). All phosphate fluxes (Fig. 2b) in the $P$. oceanica meadow during the whole experiment were significantly lower than zero (Wilcoxon test; $p<0.01$ ), while $70 \%$ of the phosphate fluxes in unvegetated sediment were not significantly lower than zero (Wilcoxon test; $\mathrm{p}>0.05$ ). Annually, P. oceanica communities supported a net uptake of phosphate of $9.4 \pm$ $3.5 \mathrm{mmol} \mathrm{P} \mathrm{m} \mathrm{yr}^{-1}$, which was significantly different from zero $(t$-test; $\mathrm{p}<0.05)$, while the annual net uptake in unvegetated sediment was much lower $(0.5 \pm$ $1.7 \mathrm{mmol} \mathrm{P} \mathrm{m}^{-2} \mathrm{yr}^{-1}$ ), but still significantly different from zero ( $t$-test; $\mathrm{p}<0.05$ ) (Table 1$)$. On an annual scale, unvegetated sediment communities were a net source of ammonium of $5.1 \pm 16.1 \mathrm{mmol} \mathrm{N} \mathrm{m} \mathrm{Nr}^{-1}$, which was a rate significantly different from zero ( $t$-test; $\mathrm{p}<0.05$ ).

Bare sediments oscillated between acting as a net sink of DOC in the spring of 2001 and the fall of 2002, to a net source of DOC in the summer of 2001 (Fig. 3a). A maximum DOC release of $14.5 \pm 5.6 \mathrm{mmol} \mathrm{C} \mathrm{m} \mathrm{m}^{-2} \mathrm{~d}^{-1}$ was observed in June 2002 and was statistically significant ( $t$-test; $\mathrm{p}<0.05$ ). Posidonia oceanica communities generally supported a net release of DOC, with a maximum release rate of $34.7 \pm 4.1 \mathrm{mmol} \mathrm{C} \mathrm{m}^{-2} \mathrm{~d}^{-1}$ significantly different from zero ( $t$-test; $p<0.05$ ) in June 2002. Both communities followed roughly similar patterns, with higher DOC release rates in summer. P. oceanica communities had, annually, a DOC release of $4359.7 \pm 936.9 \mathrm{mmol} \mathrm{C} \mathrm{m}^{-2} \mathrm{yr}^{-1}$, which differed significantly from zero ( $t$-test; $\mathrm{p}<0.05$; Table 1$)$. Of the DOC fluxes in the $P$. oceanica meadow, $94 \%$ were significantly higher (Wilcoxon test; $\mathrm{p}<0.01$ ) than zero, while half of the DOC fluxes in the unvegetated sediment were not significantly higher than zero (Wilcoxon test; $\mathrm{p}>$ 0.05). P. oceanica communities generally supported a net DON release (Fig. 3b); however, these fluxes were not significantly higher than zero (Wilcoxon test; $\mathrm{p}>0.05$ ). The temporal pattern of net DON fluxes was comparable for unvegetated sediment and $P$. oceanica communities, with the only exception observed in the summer of 2002. Minimum net DON 
Table 1. Net community production (NCP), dissolved organic carbon (DOC), dissolved organic nitrogen (DON), dissolved organic phosphorus (DOP), nitrate, phosphate and ammonium release in Posidonia oceanica and unvegetated sediment. Monthly fluxes $\left(\mathrm{mmol} \mathrm{m}^{-2} \mathrm{~d}^{-1}\right)$ and annual fluxes $(\mathrm{mmol}$ $\mathrm{m}^{-2} \mathrm{yr}^{-1}$ ) are given as means $\pm \mathrm{SE}$. Positive values mean net release, while negative values mean uptake. NCP values were obtained from C. Barrón et al. (unpubl. data). * significantly different from zero $(t$-test, $\mathrm{p}<0.05)$

\begin{tabular}{|c|c|c|}
\hline Flux & P. oceanica & Sediment \\
\hline \multicolumn{3}{|l|}{ NCP } \\
\hline Min. & $-24.7 \pm 7.0$ & $-4.8 \pm 0.8$ \\
\hline Max. & $88.8 \pm 6.4$ & $5.0 \pm 0.3$ \\
\hline Mean & $6085.6 \pm 1832.5^{*}$ & $-140.9 \pm 178.0$ \\
\hline \multicolumn{3}{|l|}{ Nitrate } \\
\hline Min. & $-0.2 \pm 0.1$ & $0.0 \pm 0.0$ \\
\hline Max. & $0.0 \pm 0.0$ & $0.1 \pm 0.1$ \\
\hline Mean & $10.2 \pm 4.6^{*}$ & $4.0 \pm 3.2^{*}$ \\
\hline \multicolumn{3}{|l|}{ Phosphate } \\
\hline Min. & $-0.1 \pm 0.1$ & $0.0 \pm 0.0$ \\
\hline Max. & $0.0 \pm 0.0$ & $0.0 \pm 0.1$ \\
\hline Mean & $-9.4 \pm 3.5^{*}$ & $-0.5 \pm 1.7^{*}$ \\
\hline \multicolumn{3}{|l|}{ Ammonium } \\
\hline Min. & $-0.4 \pm 0.5$ & $-0.2 \pm 0.1$ \\
\hline Max. & $1.0 \pm 0.0$ & $0.3 \pm 0.3$ \\
\hline Mean & $36.5 \pm 33.9$ & $5.1 \pm 16.1^{*}$ \\
\hline \multicolumn{3}{|l|}{ DOC } \\
\hline Min. & $2.1 \pm 0.3$ & $-10.8 \pm 4.1$ \\
\hline Max. & $34.7 \pm 4.1$ & $14.5 \pm 5.6$ \\
\hline Mean & $4359.7 \pm 936.9^{*}$ & $-245.1 \pm 551.6$ \\
\hline \multicolumn{3}{|l|}{ DON } \\
\hline Min. & $-1.7 \pm 0.2$ & -1.8 \\
\hline Max. & $0.9 \pm 0.3$ & $0.5 \pm 0.3$ \\
\hline Mean & $4.4 \pm 53.9$ & $-113.5 \pm 55.1^{*}$ \\
\hline \multicolumn{3}{|l|}{ DOP } \\
\hline Min. & $0.0 \pm 0.0$ & 0.0 \\
\hline Max. & $0.0 \pm 0.0$ & $0.0 \pm 0.0$ \\
\hline Mean & $1.7 \pm 1.3^{*}$ & $0.4 \pm 0.4$ \\
\hline \multicolumn{3}{|l|}{ DOC:DON } \\
\hline Min. & 3 & $1 \pm 1$ \\
\hline Max. & 205 & $118 \pm 106$ \\
\hline Mean & $42 \pm 9^{*}$ & $34 \pm 14^{*}$ \\
\hline \multicolumn{3}{|l|}{ DON:DOP } \\
\hline Min. & 4 & 16 \\
\hline Max. & 742 & 161 \\
\hline Mean & $69 \pm 36^{*}$ & $66 \pm 17^{*}$ \\
\hline \multicolumn{3}{|l|}{ DOC:DOP } \\
\hline Min. & $354 \pm 83$ & 22 \\
\hline Max. & $4096 \pm 2865$ & 2266 \\
\hline Mean & $1450 \pm 367^{*}$ & $1023 \pm 414^{*}$ \\
\hline DOM (C:N:P) & $1450: 69: 1$ & 1023:66:1 \\
\hline
\end{tabular}

uptake rates of $1.7 \pm 0.2$ and $1.8 \pm 0.2 \mathrm{mmol} \mathrm{N} \mathrm{m}{ }^{-2} \mathrm{~d}^{-1}$ were observed in October 2002 (Fig. 3b) in P. oceanica and unvegetated sediments, respectively; these values were significantly different from zero $(t$-test; $\mathrm{p}<0.01)$. Annually, unvegetated sediment communities gener-
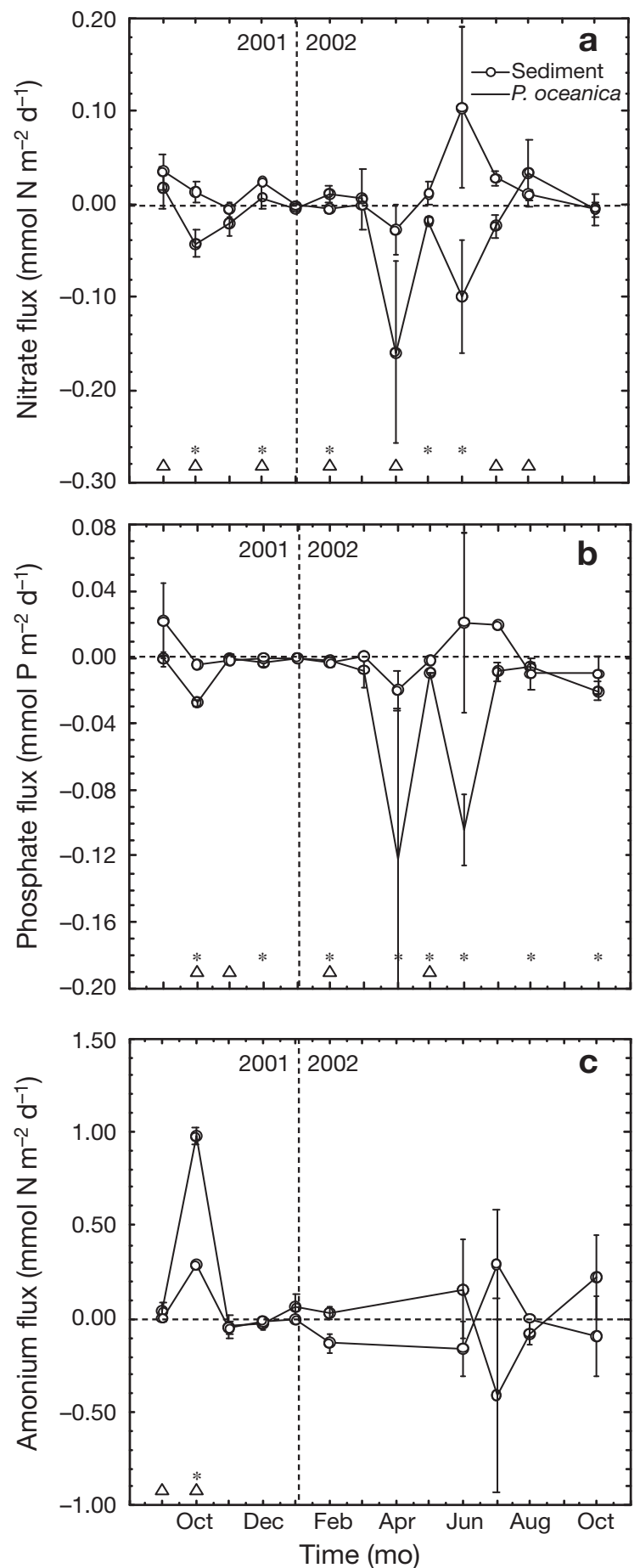

Fig. 2. Time course of: (a) net nitrate flux ( $\left.m m o l ~ \mathrm{~N} \mathrm{~m}^{-2} \mathrm{~d}^{-1}\right)$, (b) net phosphate flux (mmol $\mathrm{P} \mathrm{m}^{-2} \mathrm{~d}^{-1}$ ) and (c) net ammonium flux (mmol N m${ }^{-2} \mathrm{~d}^{-1}$ ) in the Posidonia oceanica meadow and in the adjacent unvegetated benthic communities during studies conducted between 2001 and 2002. Positive values represent release of nutrients while negative values represent uptake; average $\pm \mathrm{SE}$ are shown. Open triangles indicate nutrient fluxes in unvegetated sediments are significantly different from zero ( $t$-test, $\mathrm{p}<0.05)$. Asterisks indicate nutrient fluxes in $P$. oceanica are significantly different from zero $(t$-test, $\mathrm{p}<0.05)$ 

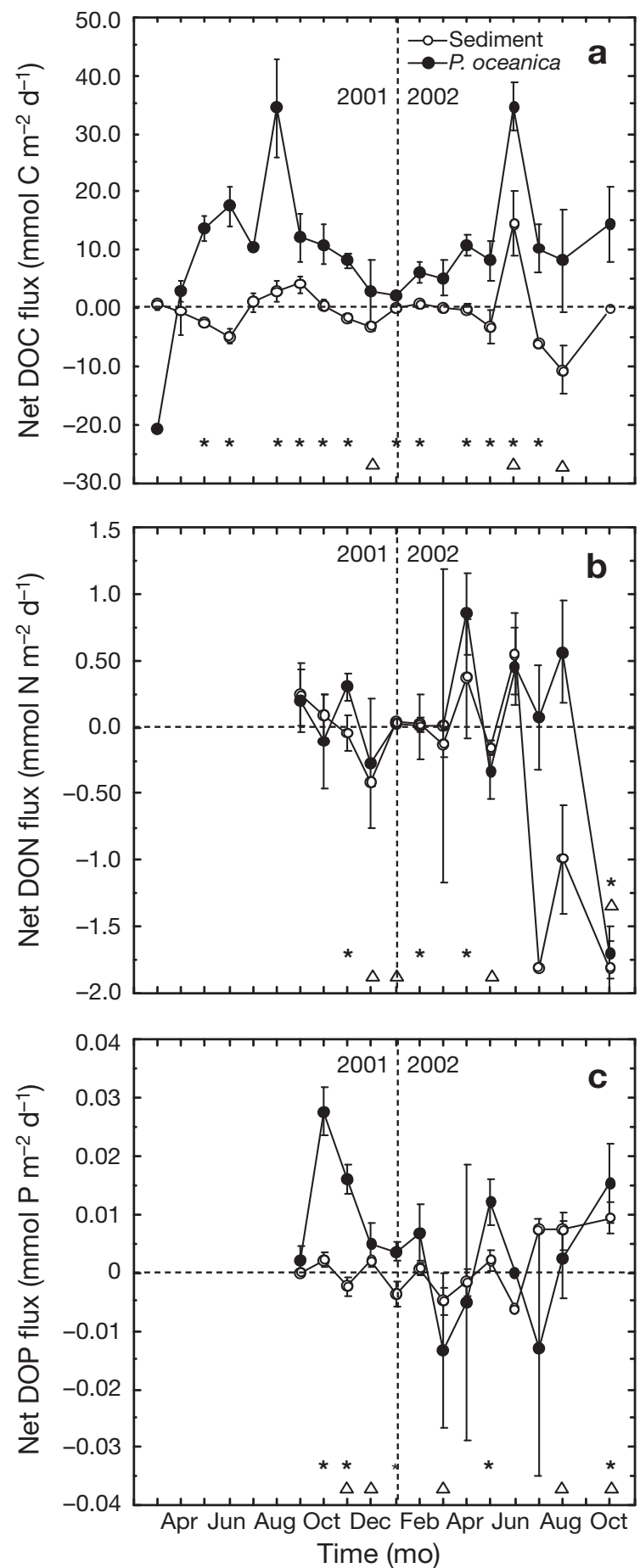

Fig. 3. (a) Net dissolved organic carbon flux (DOC; mmol $\mathrm{C} \mathrm{m}^{-2} \mathrm{~d}^{-1}$ ), (b) dissolved organic nitrogen flux (DON; mmol N $\mathrm{m}^{-2} \mathrm{~d}^{-1}$ ) and (c) dissolved organic phosphorus (DOP; mmol P $\mathrm{m}^{-2} \mathrm{~d}^{-1}$ ) in the Posidonia oceanica meadow and in the adjacent unvegetated benthic communities during 2001 and 2002. Positive values represent release and negative values represent uptake; average $\pm \mathrm{SE}$ are shown. Open triangles indicate fluxes in unvegetated sediments are significantly different from zero ( $t$-test, $\mathrm{p}<0.05)$. Asterisks indicate fluxes in $P$. oceanica are significantly different from zero $(t$-test, $\mathrm{p}<0.05)$ ally supported a net DON uptake (Table 1) of $113.5 \pm$ $55.1 \mathrm{mmol} \mathrm{N} \mathrm{m}{ }^{-2} \mathrm{yr}^{-1}$, which was significantly different from zero $(t$-test $; \mathrm{p}<0.05)$. P. oceanica communities acted as a source of DOP throughout much of the study, with particularly high rates in the summer and fall of 2001 (Fig. 3c). On an annual scale, these vegetated communities released $1.7 \pm 1.3 \mathrm{mmol} \mathrm{P} \mathrm{m}{ }^{-2} \mathrm{yr}^{-1}$, which was significantly different from zero $(t$-test; $\mathrm{p}<$ 0.05). In contrast, bare sediment communities were a sink of DOP throughout most of the study, although they released DOP during the summer of 2002. The average C:N:P ratio in the DOM flux of the $P$. oceanica community and in unvegetated sediments were 1450:69:1 and 1024:66:1, respectively.

\section{DISCUSSION}

The inorganic nutrient fluxes reported in the present study are 2- to 3-fold higher than those reported by Ziegler \& Benner (1999b) using a similar approach in unvegetated and Thalassia testudinum communities. In our study, the Posidonia oceanica communities always supported a higher net uptake of nitrate and phosphate than did unvegetated sediments. The maintenance of high productivity in this community, which has been reported to be net autotrophic on an annual scale (Gazeau et al. 2005, Barrón et al. 2006a), requires high nutrient uptake, especially when seagrass growth is highest, as in late spring to early summer (Alcoverro et al. 1995, 2000). NCP in the P. oceanica meadow studied was also highest in spring, consistent with the period of high seagrass biomass and maximum net phosphate and nitrate uptake, as expected from the seasonality of plant requirements (Alcoverro et al. 1995). The high seagrass biomass found during this period could be supported by high nutrient uptake from the surrounding water; however, retranslocation of nutrients from old leaves to new growing leaves has been found to be important, especially in this period of the year when high growth rates coincide with low nutrient concentrations in the water column (Alcoverro et al. 2000, Barrón et al. 2006b).

Comparison of the $\mathrm{N}: \mathrm{P}$ ratio in the net inorganic nutrient uptake, seagrass nutrient content and DOM release may help evaluate the processes involved (Fig. 4). The N:P ratio for inorganic nutrient uptake is 1.1 , whereas the N:P ratio in DOM released by Posidonia oceanica is $>60$ times higher. This suggests that $P$. oceanica systems must retain $\mathrm{P}$ relative to $\mathrm{N}$. We estimated the POP export to be $1.2 \mathrm{mmol} \mathrm{P} \mathrm{m}^{-2} \mathrm{yr}^{-1}$, similar to the DOP release in this seagrass system. Consequently, the annual phosphate uptake is able to support the P output from the system and allows a fraction of the $\mathrm{P}$ input to be retained in the seagrass 


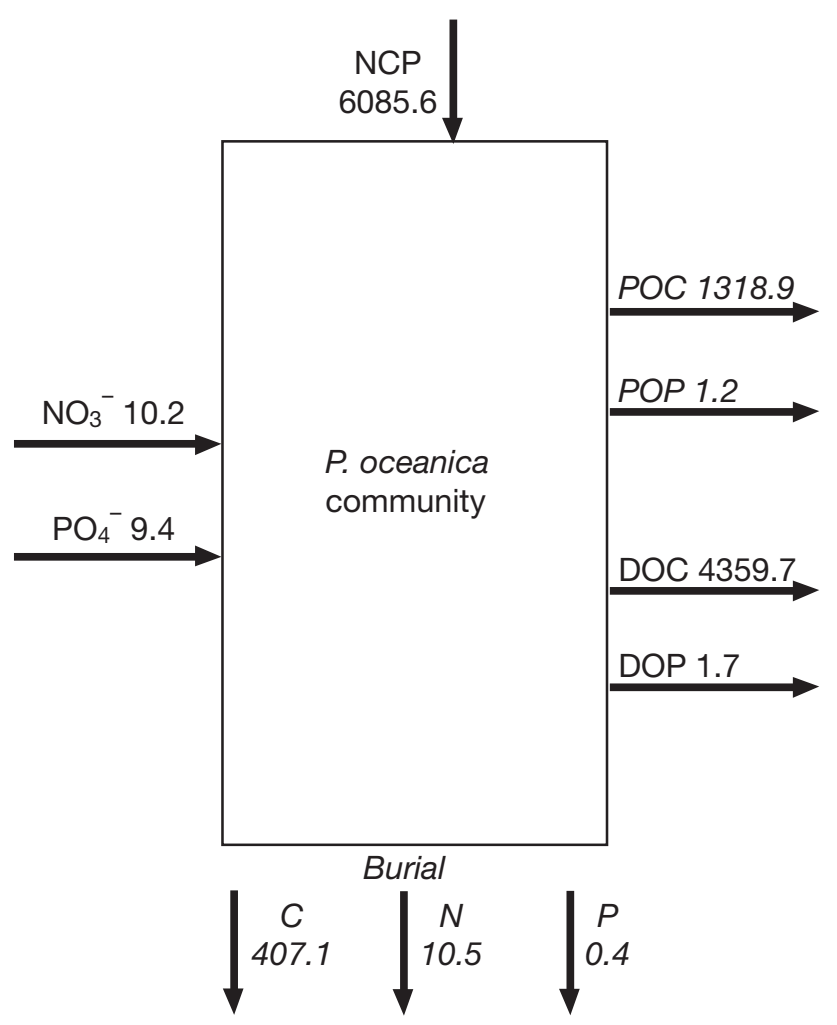

Fig. 4. Annual budget of the net community production (NCP), nitrate $\left(\mathrm{NO}_{3}^{-}\right)$and phosphate $\left(\mathrm{PO}_{4}^{-}\right)$uptake, net dissolved organic carbon (DOC) and dissolved organic phosphorus (DOP) from the Posidonia oceanica meadow (in mmol $\mathrm{m}^{-2} \mathrm{yr}^{-1}$ ). Values in italics represent calculated values. Burial of $\mathrm{C}$ was calculated as $6.8 \%$ of NCP (Duarte et al. 2005). Particulate organic carbon (POC) export was calculated by mass balance $($ POC export $=$ NCP - DOC flux - Burial $)$. Particulate organic phosphate export and burial were calculated with the $\mathrm{N}: \mathrm{C}$ and $\mathrm{P}: \mathrm{C}$ ratios of $P$. oceanica tissues and POC export and burial using seagrass $\mathrm{N}$ and $\mathrm{P}$ concentrations reduced by $40 \%$ for $\mathrm{N}$ and $59 \%$ for $\mathrm{P}$ to account for reabsorption

(Alcoverro et al. 2000)

meadow. The annual DON and $\mathrm{NH}_{4}{ }^{+}$fluxes were not significantly different from zero and should not, therefore, be important components of nitrogen cycling in the $P$. oceanica meadow. $\mathrm{N}$ burial exceeded $\mathrm{N}$ uptake by this system, suggesting that there must be additional sources of $\mathrm{N}$ inputs. Gacia et al. (2002) report that $P$. oceanica meadows trap particulate matter derived from sestonic particles, which supply much of the $\mathrm{N}$ requirements of the plants, and $P$. oceanica meadows have been identified as important sites of $\mathrm{N}$-fixation in the Mediterranean (Béthoux \& CopinMontégut 1986, Papadimitriou et al. 2005); however, the magnitude of these nitrogen inputs could not be determined in the present study.

Annually, the Posidonia oceanica meadow acted as a net source of DOC, while unvegetated sediment had a tendency to act as a weak sink of DOC. Three main processes are potentially responsible for the important net release of DOC by the seagrass system reported here: release of DOC by healthy seagrass and the associated epiphytes, release from decaying seagrass material and DOC release from decomposing sediment materials of allochthonous origin (e.g. sedimented sestonic material). Most analyses of DOC production by seagrasses report the release by laboratory-isolated seagrass. These studies have shown that the release of DOC by seagrass leaves represents $<5 \%$ of the carbon fixed during photosynthesis (Brylinsky 1977, Penhale \& Smith 1977, Wetzel \& Penhale 1979, Moriarty et al. 1986), although Kirkman \& Reid (1979) reported that $43 \%$ of the gross primary production was released as DOC from living and decaying seagrass leaves. Studies of DOC release by seagrass ecosystems are much fewer. Barrón et al. (2004) reported that, during Cymodocea nodosa colonization, community net DOC fluxes increased from a net uptake in C. nodosa patches younger than 2 yr to a net release of $81.6 \mathrm{mmol} \mathrm{C} \mathrm{m} \mathrm{m}^{-2} \mathrm{~d}^{-1}$ in the $7 \mathrm{yr}$ old patch. Velimirov (1986) showed a DOC release by a $P$. oceanica meadow of, on average, about $40.2 \mathrm{mmol}$ $\mathrm{C} \mathrm{m} \mathrm{m}^{-2} \mathrm{~h}^{-1}$; however, he reported DOC concentrations ranging from 33 to $2500 \mu \mathrm{M}$, which are exceedingly high for Mediterranean waters compared, for example, with the range of 80 to $120 \mu \mathrm{M}$ reported by Lucea et al. (2003). Ziegler \& Benner (1999a,b) estimated, using an approach similar to ours, DOC release by a Thalassia testudinum community to be between 3.5 and $24.9 \mathrm{mmol} \mathrm{C} \mathrm{m} \mathrm{C}^{-2} \mathrm{~d}^{-1}$ or about $10 \%$ of the net community production. There was little seasonal trend in the net DOC fluxes measured in the bare sediment, but the seasonal variation was higher in the T. testudinum-dominated community (Ziegler \& Benner 1999a). A similar trend was found in the P. oceanica meadow and its adjacent unvegetated sediment: net DOC fluxes decreased in fall and winter and increased slightly in spring, reaching maximum values in summer, with fluxes in the seagrass meadow being an order of magnitude larger that those in bare sediments. Our results and previous studies indicate, therefore, that seagrass communities enhance DOC fluxes relative to unvegetated sediments. The $P$. oceanica meadow we studied was an annual net source of DOC of $4359.7 \pm 936.9 \mathrm{mmol}$ $\mathrm{C} \mathrm{m} \mathrm{m}^{-2} \mathrm{yr}^{-1}$, being of the same order of magnitude as the net seagrass DOC release from $T$. testudinum. This net DOC release by the $P$. oceanica meadow represents the aggregated contribution of all sources of DOC, including the autochthonous and allochthonous components described above. The relative contribution of each of the processes cannot be discriminated from our results. 
The Posidonia oceanica meadow studied was net autotrophic, with an NCP of $6085.6 \mathrm{mmol} \mathrm{C} \mathrm{m} \mathrm{m}^{-2}$ and a DOC release equivalent to $71 \%$ of the NCP. Hence, the remaining NCP must be released as particulate organic carbon (POC) or buried in the sediment (Fig. 4). The high net DOC release relative to NCP in $P$. oceanica is likely to be supported by allochthonous inputs of sestonic materials (Gacia et al. 2002). The DOC release by the $P$. oceanica meadow was 3 -fold higher than the POC export, comparable to the reported relative magnitudes of DOC and POC export from rocky shore communities in mesocosms (Barrón et al. 2003). A significant fraction of the $C$ fixed by seagrass is released into the water column as DOM and is utilized by heterotrophic bacterioplankton (Moriarty \& Pollard 1982, Moriarty et al. 1986, Ziegler \& Benner 1999a). Most of the net benthic production must either support respiration in the above pelagic compartment (Navarro et al. 2004, Gazeau et al. 2005) or be exported to the open ocean. We estimated the total DOC flux in the Bay of Palma using the estimated net DOC fluxes of a $P$. oceanica meadow and unvegetated sediment and the net DOC fluxes reported for the planktonic community (Navarro et al. 2004). We also took into account the area covered by these communities in Palma Bay. The average water residence time was $2.5 \pm 0.2$ and $10 \mathrm{~d}$ during March and October 2002, respectively; however, the residence time in October was subjected to strong uncertainties due to the low current velocities and the consequent noise (Gazeau et al. 2005). We calculated that the net DOC release by the seagrass community can support the net DOC uptake by the unvegetated sediment and the heterotrophic metabolism in the planktonic compartment, estimated to represent a DOC uptake of $1.13 \mathrm{~g} \mathrm{C} \mathrm{m}^{-3}$ $\mathrm{yr}^{-1}$ (Navarro et al. 2004), so there will still be a net export of DOC of $3.2 \mathrm{Gg} \mathrm{C} \mathrm{yr}^{-1}$ from Palma Bay to the adjacent open waters. The total organic carbon export in the global coastal ocean, taking into account the unvegetated and vegetated habitats, has been estimated to be between 1.1 and 3.5 $\mathrm{Pg} \mathrm{C} \mathrm{yr}^{-1}$ (Duarte et al. 2005). The bulk of this organic carbon is available to be exported to the ocean, where it may be respired to support heterotrophy of the open ocean (Duarte \& Agustí 1998, del Giorgio \& Duarte 2002). However, the magnitude of the DOC export from the coastal ocean has not been addressed yet. $P$. oceanica meadows are declining in the Spanish Mediterranean at rates of about $5 \% \mathrm{yr}^{-1}$ (Marbà et al. 2005). The rapid decline of the meadows is due to a combination of causes, such as anthropogenic disturbances, including the increase in nutrient and organic matter inputs (Marbà et al. 2002, Holmer et al. 2003). Vegetated marine habitats are important sites for $\mathrm{C}$ production and export and can help subsidize the heterotrophic metabolism of the open ocean. However, the area covered by marine vegetation is rapidly declining, with an estimated loss of about $20 \%$ of the seagrass cover over the past 2 decades (Green \& Short 2003). Our results suggest that the loss of seagrass ecosystems might lead to an important loss in DOC exports from the coastal to the open ocean; however, more studies on DOC fluxes from contrasting seagrass communities must be performed in order to estimate the net DOC export from seagrass.

In contrast, seagrass meadows were a lower source of DON and DOP to the water column than for net DOC release, assuming DON and DOP fluxes in Posidonia oceanica are in the same range reported for the Thalassia testudinum community (Ziegler et al. 2004). These measured rates are even lower than expected from the DOC release, as the annual DON and DOP release represented only 1.7 and $12.2 \%$ of the $\mathrm{N}$ and $\mathrm{P}$ associated with the net community production, which was calculated from the $\mathrm{N}: \mathrm{C}$ and $\mathrm{P}: \mathrm{C}$ ratios of seagrass leaves. Reports of DOM release from seagrass meadows and the associated C:N ratios are few (Dollar et al. 1991, Ziegler et al. 2004). The C:P ratio of DOM fluxes reported for $T$. testudinum communities ranged between 1200 and 6850 in light incubations and was 240 in dark incubations (Ziegler et al. 2004), while the ratio in $P$. oceanica communities varied from 354 to 4096. All fluxes measured showed very high variability in the elemental ratios involved, suggesting wide variability in the compounds released and also suggesting high variability in the sources of the materials exchanged. The high net DOC release compared to the DON and DOP release in $P$. oceanica meadows explained why the average $C: N: P$ ratio in the DOM flux for the $P$. oceanica community (1450:69:1) was much higher than that for the seagrass leaves (497:21:1) and also why it exceeded the C:N:P ratio in the DOM flux of unvegetated sediment communities. The C:N:P atomic ratio of benthic marine macroalgae and seagrass is about 550:30:1 (Atkinson \& Smith 1983, Duarte 1990), as benthic plants are more depleted than phytoplankton in $\mathrm{P}$ and $\mathrm{N}$ relative to $\mathrm{C}$, due to their greater need for structural C. Fluxes estimated were net fluxes, so that use of DOM released within the community is already considered. This suggests that the DOM compounds used may be those with a higher $\mathrm{N}$ and $\mathrm{P}$ content, which can be more readily used by bacteria (Enríquez et al. 1993, Ziegler et al. 2004) and/or that the net DOM release is enriched in carbon compounds. The major organic compounds produced photosynthetically are carbohydrates, which are used as structural and storage compounds in marine autotrophs. Sucrose is the dominant storage carbohydrate $(90 \%$ of the total soluble carbohydrate pool). It is stored primarily in the seagrass rhizomes (Touchette \& Burkholder 2000), thus minimizing the amount of C 
lost by herbivory and ensuring that carbohydrates are stored perennially in below-surface structures (Burke et al. 1996). The non-structural carbohydrate pool is mobilized to support growth and metabolism during periods of light limitation in seagrasses generally (Burke et al. 1996, Brun et al. 2003) and in P. oceanica (Ruiz \& Romero 2001) specifically. Non-structural carbohydrate content in $P$. oceanica was highest in summer and lowest in fall and winter (Alcoverro et al. 2001). These seasonal changes in non-structural carbohydrates are in agreement with the seasonal changes in NCP and net DOC release measured in P. oceanica. For that reason, the non-structural carbohydrate pool in seagrasses might also be used to meet the net DOC release found in $P$. oceanica ecosystems; however, more studies on the characterization of DOC released by seagrass ecosystems are needed to understand the carbon budget in seagrass ecosystems.

Acknowledgements. This work was funded by the European Commission EUROTROPH project, Contract Number EVK3CT-2000-00040. C.B. was funded by a scholarship from the government of the Balearic Islands. We thank R. Martínez, R. Santiago and others who helped with fieldwork, E. DíazAlmela and J. Fourqurean for plant nutrient data, E. DíazAlmela for water temperature data, and R. Martínez and J. C. Alonso for nutrient analyses.

\section{LITERATURE CITED}

Alcoverro T, Duarte CM, Romero J (1995) Annual growth dynamics of Posidonia oceanica: contribution of largescale versus local factors to seasonality. Mar Ecol Prog Ser 120:203-210

Alcoverro T, Matanza M, Romero J (2000) Nutrient mass balance of the seagrass Posidonia oceanica: the importance of nutrient retranslocation. Mar Ecol Prog Ser 194:13-21

- Alcoverro T, Matanza M, Romero J (2001) Annual metabolic carbon balance of the seagrass Posidonia oceanica: the importance of nutrient carbohydrate reserves. Mar Ecol Prog Ser 211:105-116

Atkinson MJ, Smith SV (1983) C:N:P ratios of benthic marine plants. Limnol Oceanogr 28:568-574

Barrón C, Marbà N, Duarte CM, Pedersen MF and others (2003) High organic carbon export precludes eutrophication effects in experimental rocky shore communities. Ecosystems 6:144-153

Barrón C, Marbà N, Terrados J, Kennedy H, Duarte CM (2004) Community metabolism and carbon budget along a gradient of seagrass (Cymodocea nodosa) colonization. Limnol Oceanogr 49:1642-1651

Barrón C, Duarte CM, Frankignoulle M, Borges AV (2006a) Organic carbon metabolism and carbonate dynamics in a Mediterranean seagrass (Posidonia oceanica) meadow. Estuaries Coasts 29:417-426

Barrón C, Middelburg JJ, Duarte CM (2006b) Phytoplankton trapped within seagrass (Posidonia oceanica) sediments are a nutrient source: an in situ isotope labelling experiment. Limnol Oceanogr 51:1648-1653

Benner R, Strom M (1993) A critical evaluation of the analyti- cal blank associated with DOC measurements by hightemperature catalytic oxidation. Mar Chem 41:153-160

Béthoux JP, Copin-Montégur G (1986) Biological fixation of atmospheric nitrogen in the Mediterranean sea. Limnol Oceanogr 31:1353-1358

Brun FG, Vergara JJ, Navarro G, Hernández I, Pérez-Llorens JL (2003) Effect of shading by Ulva rigida canopies on growth and carbon balance of the seagrass Zostera noltii. Mar Ecol Prog Ser 265:85-96

Brylinsky M (1977) Release of dissolved organic matter by some marine macrophytes. Mar Biol 39:213-220

- Burke MK, Dennison WC, Moore KA (1996) Non-structural carbohydrate reserves of eelgrass Zostera marina. Mar Ecol Prog Ser 137:195-201

Carritt DE, Carpenter JH (1966) Comparison and evaluation of currently employed modifications of the Winkler method for determining dissolved oxygen in seawater; a NASCO Report. J Mar Res 24:405-408

del Giorgio PA, Duarte CM (2002) Respiration in the open ocean. Nature 420:379-384

Diaz del Rio V, Somoza L, Goy JL, Zazo C, Rey J, HernandezMolina FJ, Mateu G (1994) Mapa Fisiográfico de la Bahía de Palma. Publ Espec Inst Esp Oceanogr 16:1-39

> Dollar SJ, Smith SV, Vink SM, Obrebski S, Hollibaugh JT (1991) Annual cycle of benthic nutrient fluxes in Tomales Bay, California, and contribution of the benthos to total ecosystem metabolism. Mar Ecol Prog Ser 79:115-125

> Duarte CM (1990) Seagrass nutrient content. Mar Ecol Prog Ser 67:201-207

> Duarte CM (1991) Allometric scaling of seagrass form and productivity. Mar Ecol Prog Ser 77:289-300

> Duarte CM, Agustí S (1998) The $\mathrm{CO}_{2}$ balance of unproductive aquatic ecosystems. Science 281:234-236

Duarte CM, Cebrián J (1996) The fate of marine autotrophic production. Limnol Oceanogr 41:1758-1766

Duarte CM, Chiscano CL (1999) Seagrass biomass and production: a reassessment. Aquat Bot 1334:1-16

Duarte CM, Middelburg JJ, Caraco N (2005) Major role of marine vegetation on the oceanic carbon cycle. Biogeosciences 1:173-180

> Enríquez S, Duarte CM, Sand-Jensen K (1993) Patterns in decomposition rates among photosynthetic organisms: the importance of detritus C:N:P content. Oecologia 94:457-471

Gacia E, Granata TC, Duarte CM (1999) An approach to the measurement of particle flux and sediment retention within seagrass (P. oceanica) meadows. Aquat Bot 65:255-268

Gacia E, Duarte CM, Middelburg JJ (2002) Carbon and nutrient deposition in the Mediterranean seagrass (Posidonia oceanica). Limnol Oceanogr 47:23-32

Gattuso JP, Frankignoulle M, Wollast R (1998) Carbon and carbonate metabolism in coastal aquatic ecosystems. Annu Rev Ecol Syst 29:405-434

Gazeau F, Duarte CM, Gattuso JP, Barrón C and others (2005) Whole-system metabolism and $\mathrm{CO}_{2}$ fluxes in a Mediterranean Bay dominated by seagrass beds (Palma Bay, NW Mediterranean). Biogeosciences 2:43-60

Green EP, Short FT (2003) World atlas of seagrasses. University of California Press, Berkeley, CA

Hansen HP, Koroleff F (1999) Determination of nutrients. In: Grasshoff K, Kremling K, Ehrhardt M (eds) Methods of seawater analysis. Verlag Chemie, Weinheim, p 170-174

> Hansen JW, Thamdrup B, Jørgensen BB (2000) Anoxic incubation of sediment in gas-tight plastic bags: a method for biogeochemical process studies. Mar Ecol Prog Ser 208: 273-282

Hemminga M, Duarte CM (2000) Seagrass ecology. Cambridge University Press, Cambridge 
Hemminga MA, Harrison PG, van Lent F (1991) The balance of nutrient losses and gains in seagrass meadows. Mar Ecol Prog Ser 71:85-96

Holmer M, Duarte CM, Marbà N (2003) Sulfur cycling and seagrass (Posidonia oceanica) status in carbonate sediments. Mar Biogeochem 66:223-239

Huertel M, Gust G (1992) Solute release mechanisms from confined sediment cores in stirred benthic chambers and flume flows. Mar Ecol Prog Ser 82:187-197

Kérouel R, Aminot A (1997) Fluorometric determination of amonia in sea and estuarine waters by direct segmented flow analysis. Mar Chem 57:265-275

Kirk JTO (1983) Light and photosynthesis in aquatic ecosystem. Cambridge University Press, Cambridge

Kirkman H, Reid DD (1979) A study of the role of the seagrass Posidonia australis in the carbon budget of an estuary. Aquat Bot 7:173-183

Lucea A, Duarte CM, Agustí S, Sødergaard M (2003) Nutrient (N, P and Si) and carbon partitioning in the stratified NW Mediterranean. J Sea Res 49:157-170

Marbà N, Duarte CM, Holmer M, Martínez R and others (2002) Assessing the effectiveness of protection on Posidonia oceanica populations in the Cabrera National Park (Spain). Environ Conserv 29:509-518

Marbà N, Duarte CM, Díaz-Almela E, Terrados J and others (2005) Direct evidence of imbalanced seagrass (Posidonia oceanica) shoot population dynamics in the Spanish Mediterranean. Estuaries 28:53-62

Mateo MA, Romero J, Pérez M, Littler M, Littler DS (1997) Dynamics of millenary organic deposits resulting from the growth of the Mediterranean seagrass Posidonia oceanica. Estuar Coast Shelf Sci 44:103-110

Mateo MÁ, Sánchez-Lizaso JL, Romero J (2003) Posidonia oceanica 'banquettes': a preliminary assessment of the relevance for meadow carbon and nutrients budget. Estuar Coast Shelf Sci 56:85-90

Moriarty DJW, Pollard PC (1982) Diel variation of bacterial productivity in seagrass (Zostera capricorni) beds measured by rate of Thymidine incorporation into DNA. Mar Biol 72:165-173

Moriarty DJW, Iverson RL, Pollard PC (1986) Exudation of organic carbon by the seagrass Halodule writhtii Aschers

Editorial responsibility: Kenneth Heck, Dauphin Island, Alabama, USA and its effect on bacterial growth in the sediment. J Exp Mar Biol Ecol 96:115-126

> Navarro N, Agustí S, Duarte CM (2004) Plankton metabolism and dissolved organic carbon use in the Bay of Palma, NW Mediterranean Sea. Aquat Microb Ecol 37: $47-54$

Oudot C, Gerard R, Morin P, Gningue I (1988) Precise shipboard determination of dissolved oxygen (Winkler procedure) for productivity studies with a commercial system. Limnol Oceanogr 33:146-150

Papadimitriou S, Kennedy H, Kennedy DP, Duarte CM, Marbà N (2005) Sources of organic matter in seagrass-colonized sediments: a stable isotope study of the silt and clay fraction from Posidonia oceanica meadows in the western Mediterranean. Org Geochem 36:949-961

$>$ Pedersen MF, Borum J (1993) An annual nitrogen budget for a seagrass Zostera marina population. Mar Ecol Prog Ser 101:169-177

Penhale PA, Smith WO (1977) Excretion of dissolved organic carbon by eelgrass (Zostera marina) and its epiphytes. Limnol Oceanogr 22:400-407

Ruiz JM, Romero J (2001) Effects of in situ experimental shading on the Mediterranean seagrass Posidonia oceanica. Mar Ecol Prog Ser 215:107-120

Touchette BW, Burkholder JM (2000) Overview of the physical ecology of carbon metabolism in seagrasses. J Exp Mar Biol Ecol 250:169-205

Velimirov B (1986) DOC dynamics in a Mediterranean seagrass system. Mar Ecol Prog Ser 28:21-41

- Wetzel RG, Penhale PA (1979) Transport of carbon and excretion of dissolved organic carbon by leaves and roots/ rhizomes in seagrasses and their epiphytes. Aquat Bot 6: 149-158

Ziegler S, Benner R (1999a) Dissolved organic carbon cycling in a subtropical seagrass-dominated lagoon. Mar Ecol Prog Ser 180:149-160

Ziegler S, Benner R (1999b) Nutrient cycling in the water column of a subtropical seagrass meadow. Mar Ecol Prog Ser 188:51-62

Ziegler S, Kaiser E, Benner R (2004) Dynamics of dissolved organic carbon, nitrogen and phosphorus in a seagrass meadow of Laguna Madre, Texas. Bull Mar Sci 75:391-407

Submitted: May 30, 2007; Accepted: August 28, 2008

Proofs received from author(s): December 14, 2008 